\title{
Statistically-based analysis of the electricity market price drivers
}

\author{
Mario Turcik ${ }^{1}$, \\ Irina Oleinikova ${ }^{1}$, \\ Michal Kolcun ${ }^{2}$ \\ ${ }^{1}$ Laboratory of Power Systems \\ Mathematical Modelling, \\ Institute of Physical Energetics, \\ Aizkraukles 21, LV-1006 Riga, Latvia \\ E-mail: turcik.mario@gmail.com \\ ${ }^{2}$ Department of Electric \\ Power Engineering, \\ Technical University of Kosice, \\ Masiarska 74, 04201 Kosice, Slovakia
}

\begin{abstract}
The aim of this paper focuses on the analysis of system spot price formation factors formed by the organized electricity market operated by the Nord Pool Spot power exchange. Analysis and statistical evaluation of historical data has been performed in order to identify and rank factors according to the price impact as well as to analyze their seasonal weight. Results of this analysis should contribute to the understanding of main drivers in the system price formation; reveal possible reasons of seasonal system price fluctuations as well as occasional unpredictable price spikes which are a common feature of the spot markets.
\end{abstract}

Key words: electricity price, market analysis, liberalisation, electricity market

\section{INTRODUCTION}

Determination of electricity prices whether in rigidly controlled or liberalized electric power industry has been and still is addressed. After introduction of liberalisation, the wholesale price for electricity is formed in the market environment by demand and supply, likewise on markets with other commodities. However, the electricity price is dependent on more factors comparing to other usual commodities. Furthermore, principles of price-based control of electrical power systems, the proclaimed role of electricity prices as the main driver for investments into modernization and new projects require good understanding of price formation factors for short-term as well as long-term purposes.

In general, the end-user electricity price could be divided into 2 main parts. The first regulated part mainly includes costs of transmission and distribution and other costs, such as subsidy of power production from RES as well as ancillary services, though a new trend leads to the purchasing of ancillary services based on market principles as well. The second deregulated part represents a part of the end-user electricity price that has been determined by the market environment. This part covers mainly costs of production / purchase of electricity, the profit margin of traders and other smaller components. The final share is roughly within $40 \%$ to $50 \%$ of the end-user electricity price and slightly varies between EU states. The structure of the enduser electricity price is shown in Fig. 1 below.

The market with electricity means that the price is determined by market participants $[1,2]$. The electricity price may be formed through organized markets where determination of the volume as well as the price is performed according to the predefined rules of the Power Exchange (PX) 


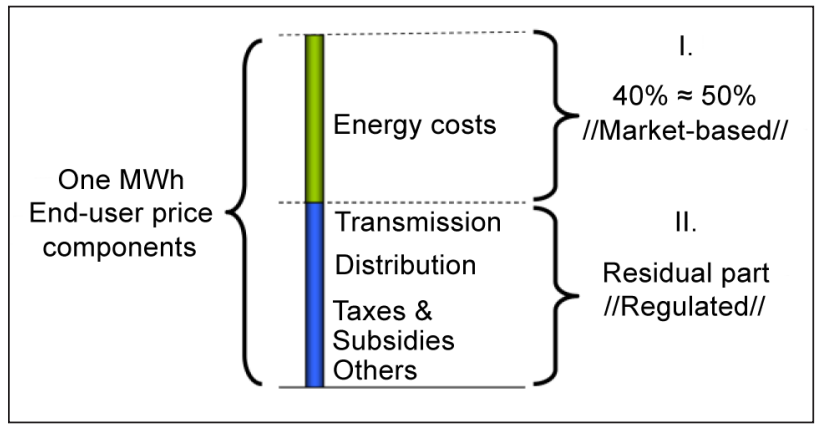

Fig. 1. End-user price components

or through non-organized markets with electricity covered by the so-called Over-the-Counter contracts (OTC) of bilateral trading.

In this article, price formation is analyzed including selected factors with the expected highest impact on the system price in the organized power market operated by the Nord Pool Spot power exchange (NPS PX). Price is always the result of the relationship between supply and demand, affected by many parameters. Therefore, the aim of analysis will be focused on finding what and how in this market influences the price of electricity. The analysis tries to find answers and in detail points out the following questions:

- How is the supply side correlated with the global fuel markets?

- How sensitive is the spot price to the fluctuations on fossil fuel markets?

- Is there an impact from introduction of $\mathrm{CO}_{2}$ emission allowances to the spot price?

- What are the main price drivers on NPS PX?

- How demand side is influencing the spot price formation?
Furthermore, in this article presented analysis points to several questions that could be addressed by the future work.

\section{SPOT PRICE FORMATION BY ORGANIZED POWER EXCHANGE}

The market clearing price $(\mathrm{MCP})$ and the market clearing volume (MCV) are determined through a two-sided auction from the intersection of the supply curve that is constructed from aggregated supply bids and the demand curve that is constructed from aggregated demand bids $[3,4]$.

A system price is created as an intersection of aggregated supply and demand bids from all bidding areas into two curves respectively. In this step of the price formation process, available trading capacities between bidding areas are not taken into account, hence considered as infinite $(\infty)$. In all situations when contractual flow between bidding areas in particular hour (hourly trading) is within the limits appointed by TSOs, thus lower or equal to the allocated commercial transmission capacity, the system price is identical to the area prices.

Formation of the wholesale electricity system price by two-sided auction (PX) is shown in Fig. 2.

\section{Supply \& Demand curve analysis}

Supply curve as aggregation of sell orders of the power producers might in a case of sufficient production capacities on market reflect their short-run marginal costs of production. Expressed in the basic form, total costs of electricity produced in the power plant consist of fixed and variable costs:

$$
C_{\text {total }}=C_{\text {fix }}+C_{\text {var }}
$$

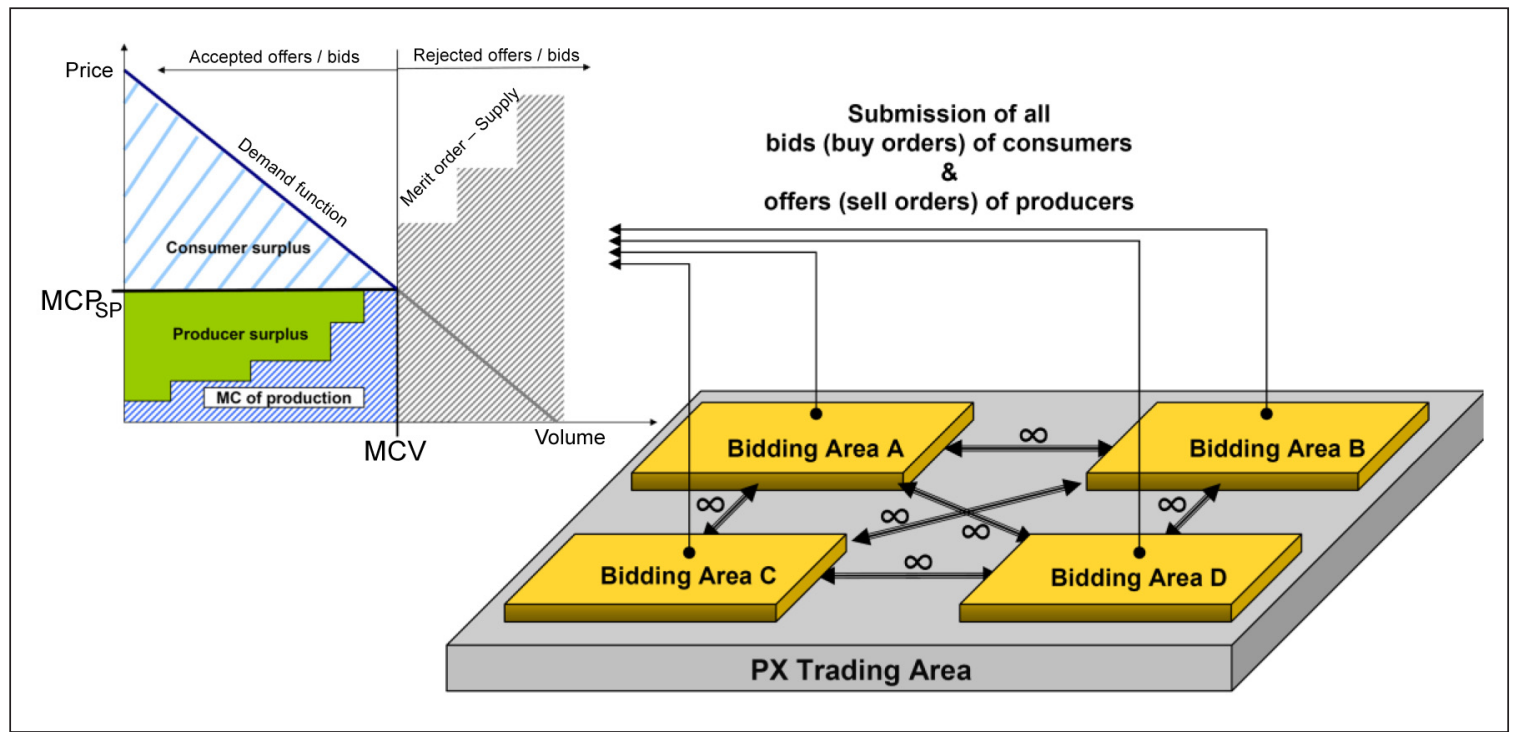

Fig. 2. System spot price formation principle 


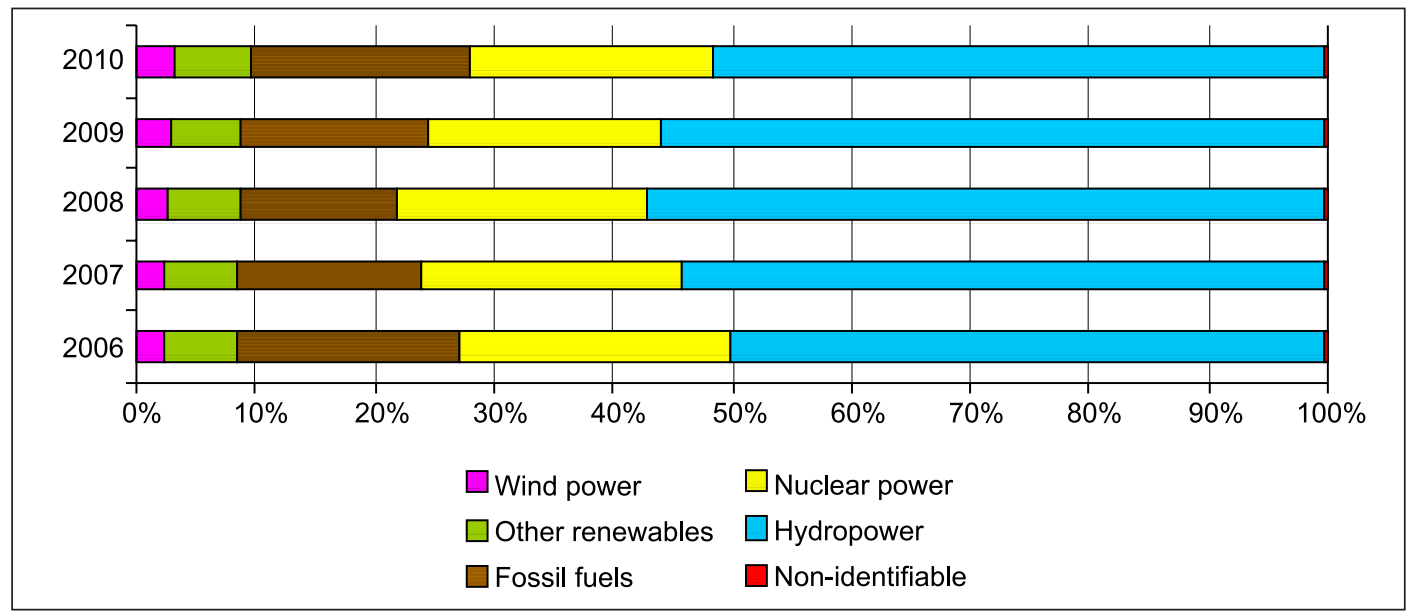

Fig. 3. Nordic area electricity production 2006-2010 by energy source

Fixed costs $C_{\text {fix }}$ are related mostly to investment and economic profit to be earned, in short-run its $\mathrm{O} \& \mathrm{M}$, wages, depreciation, social fund and other obligations that are fixed and independent on the level of production. Variable costs $C_{\text {var }}$ are all costs that depend on the level of production in a particular power plant. Mostly they cover costs of fuel and emission allowances. However, once a plant is commissioned, the marginal cost of producing an additional unit of electricity should determine its operation (dispatch). Marginal costs roughly correspond to fuel costs and costs to purchase emission allowances as their volume also depends on the level of production. This fact is important because it determines the merit order of power plants in the supply curve according to marginal costs, thereby the marginal generator and thus MCP on the electricity market. Due to that reason, gas and coal-fired power plants are in many cases the marginal plants that set the price in competitive markets [5]. Hence, increases in gas or coal prices are passed on as increases in wholesale electricity prices.

Demand curve is constructed from aggregated demand bids, thus bidding strategy of customers has a significant impact on the position of the intersection point and, therefore, final values of MCP as well as MCV on the spot market. Natural seasonal load variation of the system has of course an impact on the level of purchased electricity (demand) through spot markets which there causes natural seasonal price variations as well. Same as for the production curve, the structure of customers willing to buy electricity has to be investigated in order to obtain a comprehensive overview of spot price formation factors.

Aforementioned principles of spot price formation are also applied on the Nord Pool Spot PX the data of which have been used for analysis. The Nord Pool Spot algorithm ensures that the lowest-priced source of energy is produced by matching a consumers bid and the last MWh of energy to be produced sets the price for all previous production [3].

\section{ANALYSIS OF THE SYSTEM PRICE FORMATION FACTORS}

Analysis of the historical curve of the system price of electricity on the Nord Pool Spot and analysis of other selected factors such as coal, gas, $\mathrm{CO}_{2}$ and hydro resources have been performed in order to estimate dependency and behaviour (changes) of the system price according to changes of those factors. The first reflection of the weight of selected factors could provide the proportionality of energy sources in the total produced power by the production mix of Nordel (DK, SWE, FIN, NOR) in Fig. 3.

Considerable long-term hydro production may be a signal of weighty influence of the hydro resources to the system price, however, according to the principles of spot price formation (marginal generator), relation of hydro resources and system prices must be investigated in detail. The nuclear production seems to be a type of production with low historical price volatility. In addition, those types of plants traditionally working into the base load and on organized spot market usually do not play the role of the marginal generator. Hence, a deeper investigation of impacts on the system price is not performed for this type of power plants. However, power plants operated on fossil fuels such as gas or coal have higher marginal costs and often on spot markets play the role of the marginal generator (determine market price). Hence, even though production of those power plants is not proportionally highest, it significantly influences electricity prices. Tight correlation of plants operated on fossil fuels may be additionally expected with $\mathrm{CO}_{2}$ emissions as a part of their marginal costs (except fuel costs).

Same as the prices of other commodities, the prices of fossil fuels experience wide price swings in times of shortage or oversupply. The price cycles may extend over several years responding to the changes in supply and demand [6]. 
Past decade development in fossil fuels and emission prices

Gas. The gas spike of the last decade occurred in 2008. Regional spot prices and oil-linked gas prices peaked at levels between USD 13 and 15 per MMBtu (1 $000000 \mathrm{Btu}=\mathrm{MMB}$ $\mathrm{tu})$. Oil-linked gas prices in Japan and Continental Europe continued to increase throughout much of 2008 due to the time lag embedded in the contract formulas, but were declining in 2009 to reach USD 7 per MMBtu in the summer of 2009 [7]. However, spot prices started declining in mid2008 reflecting the impact of the economic crisis on gas demand. Depending on the speed and geographical scope of economic recovery, spot gas prices may well remain weak for some years.

Coal. Since 1980 to 2003 a coal price has been relatively stable with a general downward tendency and fluctuation due to the natural global economical cycles. Since 2003 the rapid economic growth in China and other developing countries had a major impact on the world coal production redistribution. To meet the rising demand, international coal trade grew by an average of $6.4 \%$ per year between 2003 and 2007. Unprecedented spike in the coal trade price came up in 2007 and early 2008 due to the sharp increase of demand. Decrease of coal prices has been caused mostly by global recession. Although most coal is sold under contract and changes in spot markets take time to filter through into prices paid by coal customers, even there contract prices are linked to spot market prices [7].

$\mathrm{CO}_{2}$ emission allowances. Since introduction of the European trading system with emission allowances, those became an important factor which has impact on electricity prices. $\mathrm{CO}_{2}$ allowances are assumed the same as for other commodities, thus can be purchased as well as sold according to the best, most profitable actual option for the generator [8]. Even when generators received allowances for free, those opportunity costs are more or less reflected to the electricity prices.

\section{CORRELATION AND REGRESION ANALYSIS FOR REAL DATA SETS}

Background for correlation and regression in data analysis

Correlation investigating the nature of the relationship between different variables is an important way of numerically quantifying the relationship between them. In other words, correlation is a numerical measure of the degree to which patterns in $X$ and $Y$ correspond.

In our analysis for the quantification of the correlation the Pearson product-moment correlation coefficient (PPMCC) denoted as $r$ has been used. PPMCC is a measurement of the linear dependence between two variables $X$ and $Y$ and ranging within 1 to 1 . Positive values of $r$ indicate a positive correlation between $X$ and $Y$. Negative values indicate a negative correlation. $r=0$ indicates that $X$ and $Y$ are uncorrelated. In principle, the correlation between $X$ and $Y$ is equal to the correlation between $Y$ and $X$. The value of $r$ is not dependent on units in which analyzed variables are given. The Pearson product-moment correlation coefficient is calculated as follows:

$$
r=\frac{\sum_{i=1}^{n}\left(X_{i}-\bar{X}\right)\left(Y_{i}-\bar{Y}\right)}{\sqrt{\sum_{i=1}^{n}\left(X_{i}-\bar{X}\right)^{2}} \sqrt{\sum_{i=1}^{n}\left(Y_{i}-\bar{Y}\right)^{2}}} .
$$

However, the correlation does not necessarily imply causality. Therefore, regression as the related concept which is essentially an extension of the correlation that introduces an aspect of causality has to be employed in data analysis. Assume that a linear relationship between $Y$ and $X$ exists, and then their relationship is mathematically expressed as:

$$
Y=\alpha+\beta X,
$$

where $\alpha$ is the intercept of the line and $\beta$ is the slope. This equation is referred to as the regression line. In particular, a straight line drawn through the points on the XY-plot provides a convenient summary of the relationship between $X$ and $Y$. In the regression analysis, we formally analyze this relationship. However, it should be noted that the linear regression model will always be only an approximation of the true relationship and it has to be taken into account in conclusions based on the results obtained through such technique [9]. Data analysis has been performed in the Statistica and Excel software.

Correlation analysis and estimation of linear trends of variables

According to development tendencies of global fuel prices and emission trading, it could be anticipated that those changes will affect electricity prices by changes in production costs. Measurement of the correlation by the Pearson product-moment correlation coefficient $(r)$ was performed between daily average values of the Nord Pool Spot system price (NPSsp) and daily average values of 4 factors: petroleum price denoted as PT Brent, natural gas price index SPCTTTFCALFR1, hereinafter "Gas", price index All Published Index number 2 (API2), hereinafter "Coal”, and $\mathrm{CO}_{2}$ emmision allowances.

In order to depict seasonal differences within the year and in the entire time period under investigation (2006-2011), every year was divided into 4 equal periods ( 3 months). The results of the correlation analysis are shown in Fig. 4.

From the correlation of NSPsp with other variables (Fig. 4) connection with historical development of fuels and 


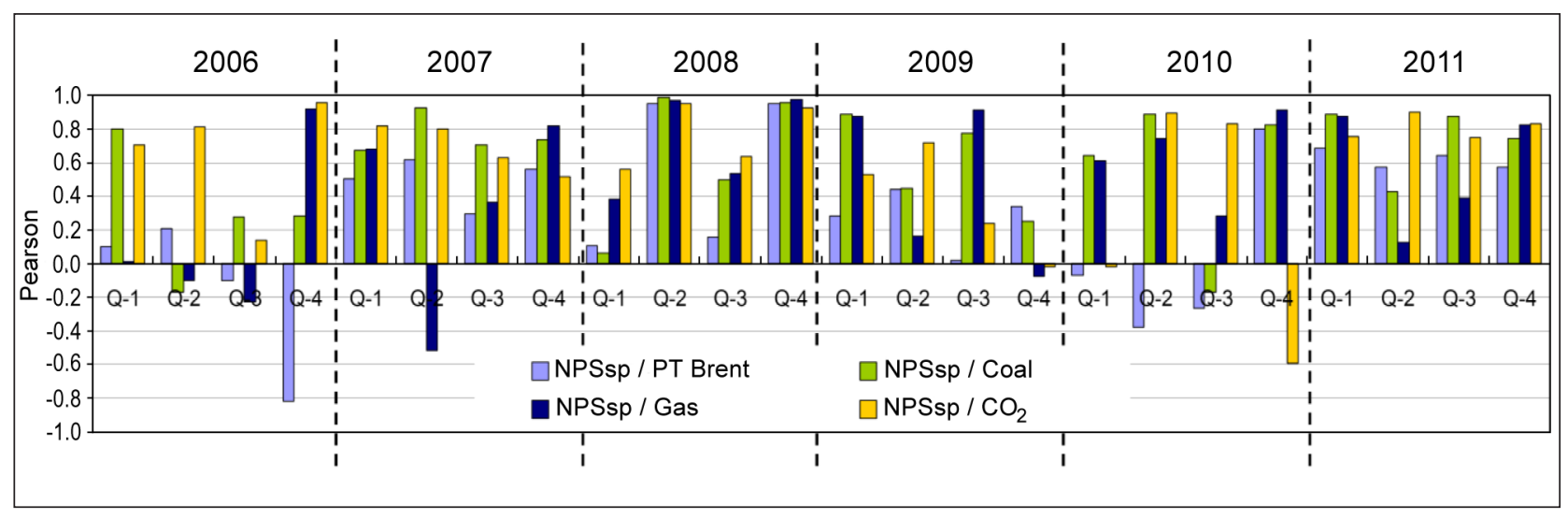

Fig. 4. Correlation of the NPS system price with examined factors

emissions is obvious, especially in quarters 2 and 4 of 2008 when fossil fuels on world markets reached peak values. Except isolated cases, the vast majority of values demonstrate a positive correlation. Significant quarterly observed differences could be explained by fluctuations of fuel and emission prices as well as differences in demand, thus by different marginal generators on spot market.

Estimation of linear trends of variables. In order to compare general tendencies and dynamism in change of variables (NPSsp, PT Brent, Gas, Coal, $\mathrm{CO}_{2}$ ) to find out their mutual behaviour, these are modelled using the linear regression model. The independent variable is in this case represented by time ( $X$ axis), while the dependent variable ( $Y$ axis) represents values of NPSsp, PT Brent, Gas, Coal and $\mathrm{CO}_{2}$. The linear regression model is fitted using the method of least squares. Input data as well as annual splitting to the quarters is the same as for the correlation analysis above.

The obtained results show general linear trend development of the particular variable in the quarter; to visualise results in the most transparent way, those linear trends are moved to the common initial point as is shown on Fig. 5.

Successive scrutiny of all quarters one-by-one from 2006 to 2011 (thus 24 quarters) reveals similarities in general trends and, furthermore, in dynamics of the upward and downward pace between variables as well as their seasonal tendencies. Gas has the highest number of identical tendency with NPSsp from all investigated factors (19 quarters from 24 quarters), the second is Coal (18 from 24), then $\mathrm{CO}_{2}$ (15 from 24) and the same for PT Brent. This result could be explained by already mentioned fact that the marginal generator is often the gas or coal-fired power plant.

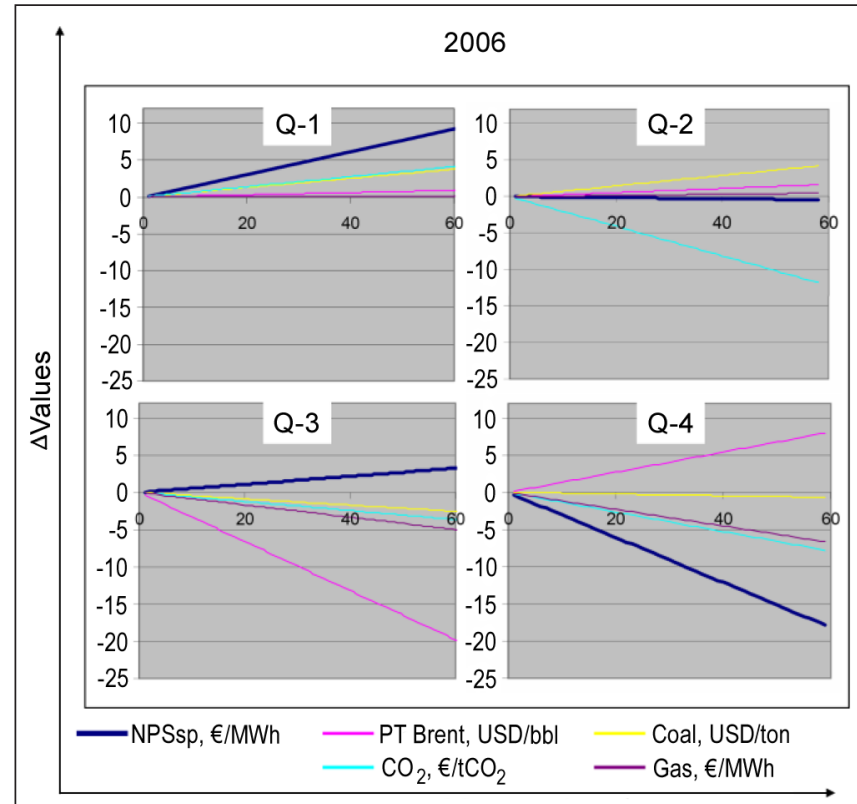

Durations of Quarters, days

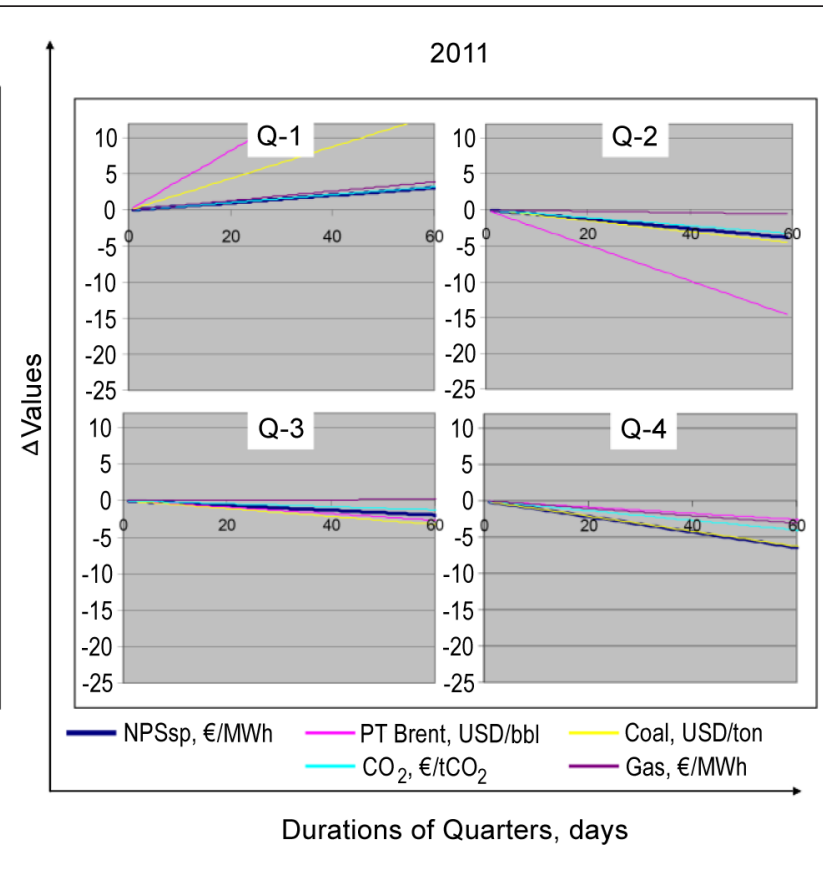

Fig. 5. Quarterly expressed linear trends of the NPS system price and examined factors (examples for 2006 and 2011) 
Table 1. Quarterly expressed R-squared values

\begin{tabular}{|c|c|c|c|c|c|c|c|c|c|c|c|c|}
\hline \multirow{2}{*}{$R \wedge 2$} & \multicolumn{6}{|c|}{ Q-1 } & \multicolumn{6}{|c|}{ Q-2 } \\
\hline & 2006 & 2007 & 2008 & 2009 & 2010 & 2011 & 2006 & 2007 & 2008 & 2009 & 2010 & 2011 \\
\hline NPS, $€ / M W h$ & 0.891 & 0.158 & 0.101 & 0.308 & 0.342 & 0.380 & 0.001 & 0.912 & 0.952 & 0.185 & 0.357 & 0.393 \\
\hline PT Brent, USD/bbl & 0.012 & 0.785 & 0.579 & 0.236 & 0.076 & 0.870 & 0.024 & 0.441 & 0.923 & 0.883 & 0.484 & 0.553 \\
\hline Coal, USD/ton & 0.575 & 0.620 & 0.732 & 0.429 & 0.792 & 0.639 & 0.694 & 0.885 & 0.945 & 0.361 & 0.405 & 0.353 \\
\hline $\mathrm{CO}_{2}, € / \mathrm{tCO}_{2}$ & 0.638 & 0.005 & 0.017 & 0.140 & 0.093 & 0.864 & 0.330 & 0.700 & 0.894 & 0.001 & 0.306 & 0.530 \\
\hline Gas, €/MWh & 0.001 & 0.011 & 0.389 & 0.504 & 0.937 & 0.722 & 0.073 & 0.263 & 0.955 & 0.103 & 0.901 & 0.079 \\
\hline \multirow{2}{*}{$R^{\wedge} 2$} & \multicolumn{6}{|c|}{ Q-3 } & \multicolumn{6}{|c|}{ Q-4 } \\
\hline & 2006 & 2007 & 2008 & 2009 & 2010 & 2011 & 2006 & 2007 & 2008 & 2009 & 2010 & 2011 \\
\hline NPS, €/MWh & 0.166 & 0.288 & 0.001 & 0.802 & 0.242 & 0.412 & 0.916 & 0.039 & 0.909 & 0.400 & 0.779 & 0.594 \\
\hline PT Brent, USD/bbl & 0.790 & 0.000 & 0.906 & 0.093 & 0.054 & 0.040 & 0.540 & 0.567 & 0.911 & 0.091 & 0.736 & 0.074 \\
\hline Coal, USD/ton & 0.137 & 0.872 & 0.677 & 0.422 & 0.130 & 0.313 & 0.063 & 0.537 & 0.802 & 0.001 & 0.890 & 0.673 \\
\hline $\mathrm{CO}_{2}, € / \mathrm{tCO}_{2}$ & 0.515 & 0.026 & 0.255 & 0.005 & 0.404 & 0.248 & 0.936 & 0.144 & 0.866 & 0.206 & 0.654 & 0.827 \\
\hline Gas, $€ / M W h$ & 0.922 & 0.000 & 0.396 & 0.700 & 0.320 & 0.020 & 0.932 & 0.323 & 0.949 & 0.621 & 0.745 & 0.895 \\
\hline
\end{tabular}

A linear approximation to estimate tendencies of dependent variables does not need to be in quarters with high volatility (dispersion) of values appropriate one. Hence, to make conclusions about tendencies between the depicted trends, fitness of a linear regression has to be taken into account by assessment of $\mathrm{R}$-squared values $\left(\mathrm{R}^{\wedge} 2\right)$. The lower value $\left(\mathrm{R}^{\wedge} 2\right)$, the worse demonstration of such trend by the linear regression model is. Table 1 gives an overview of $\mathrm{R}$-squared values obtained from linear regression models which should be used in the assessment process.

\section{Impact of hydro resources on the NPS system price}

A considerable proportion of hydro production on the overall Nordel electricity production naturally defines the dependency of the Nord pool system price on hydro resources, thus a higher correlation between them is expected. For the hydrological situation there is a typical seasonal variation as well as year-to-year differences and those are susceptible to the weather conditions. Deviation of electricity production capacities of hydro power plants from the normal average level has an impact on the electricity prices. In order to investigate those impacts find out the interdependence and strength of this relation, the average weekly potential (TWh) of Norwegian and Swedish power plants and the average weekly NPS system price (€/MWh) are input data for the analysis. The employed methodology in the regression and correlation analysis in the time period under investigation (2001-2011) includes division of every year into 3 periods (4 months each) and subsequent rearrangement of the data according to the particular period into 3 data sets. In the first data set there are values of the first periods (1/3) of all years from 2001 to 2011, the second data set contains data of the second periods (2/3) from 2001 to 2011 and the third one contains data of the third periods (3/3). Table 2 shows the results of the correlation analysis by the Pearson product-moment correlation coefficient performed for all three data sets.
The values in Table 2 show a relatively high level of the negative correlation; it could be explained that the negative deviation of hydro resources from the normal level causes an increase of prices. The result also confirms seasonal differences, thus it could be concluded that the system price in the first and third periods of the years is more "hydro dependent" than in the middle parts of the years (second periods). The linear regression analysis of 3 data sets is shown in Figs. 6, 7 and 8, respectively. The zero value of the $X$ axis represents normal hydro level, positive values (right from 0 ) level higher than the normal level and the negative value (left from 0) level lower than the normal level.

By the graphical expression of the analyzed data slightly grouping of values is obvious, so that values with higher occurrence could be observed in the particular data set. It gives an opportunity to find out a range or ranges of characteristic values in linear downward regression models. It is evident that the level of hydro reservoirs proves a relation with the system price and therefore could be concluded that it is one of the main factors in the system price determination on the Nord Pool Spot PX.

\section{CONSUMPTION / DEMAND SIDE ANALYSIS}

In order to estimate impacts of the behaviour of customers who purchase electricity on the NPS spot market on the price formation process, the strategy of their "buy" bidding was analyzed. Input data for analysis comprise 6 randomly selected days in different seasons in 2010, 2011 and 2012. Every day consists of 24 hourly results of bidding strategy. Bidding strategy means the level of "willing to pay" of

Table 2. Correlation level of hydro potential with NPS system price 2001-2011 by period

\begin{tabular}{c|c|c|c}
\hline 2001-2011 & $1 / 3$ of years & $2 / 3$ of years & $3 / 3$ of years \\
\hline Hydro/NPSsp & -0.640 & -0.453 & -0.600 \\
\hline
\end{tabular}




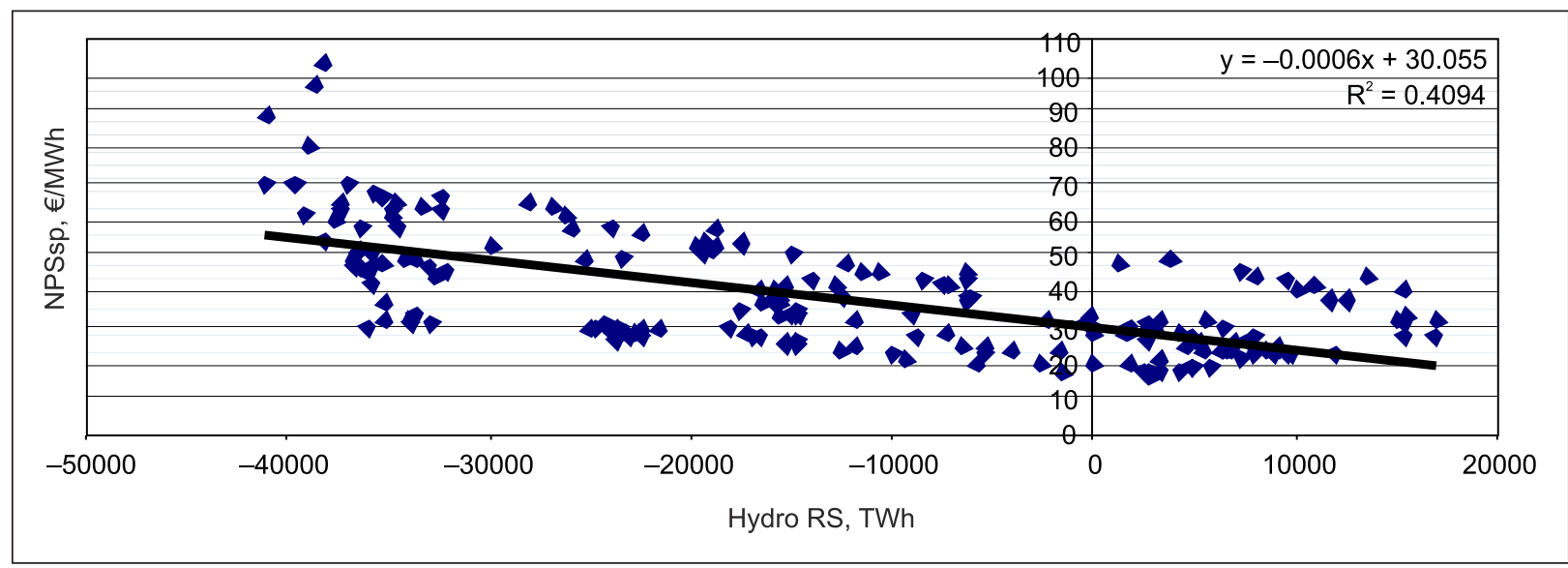

Fig. 6. Linear regression analysis of the first periods (1/3) of the years 2001-2011

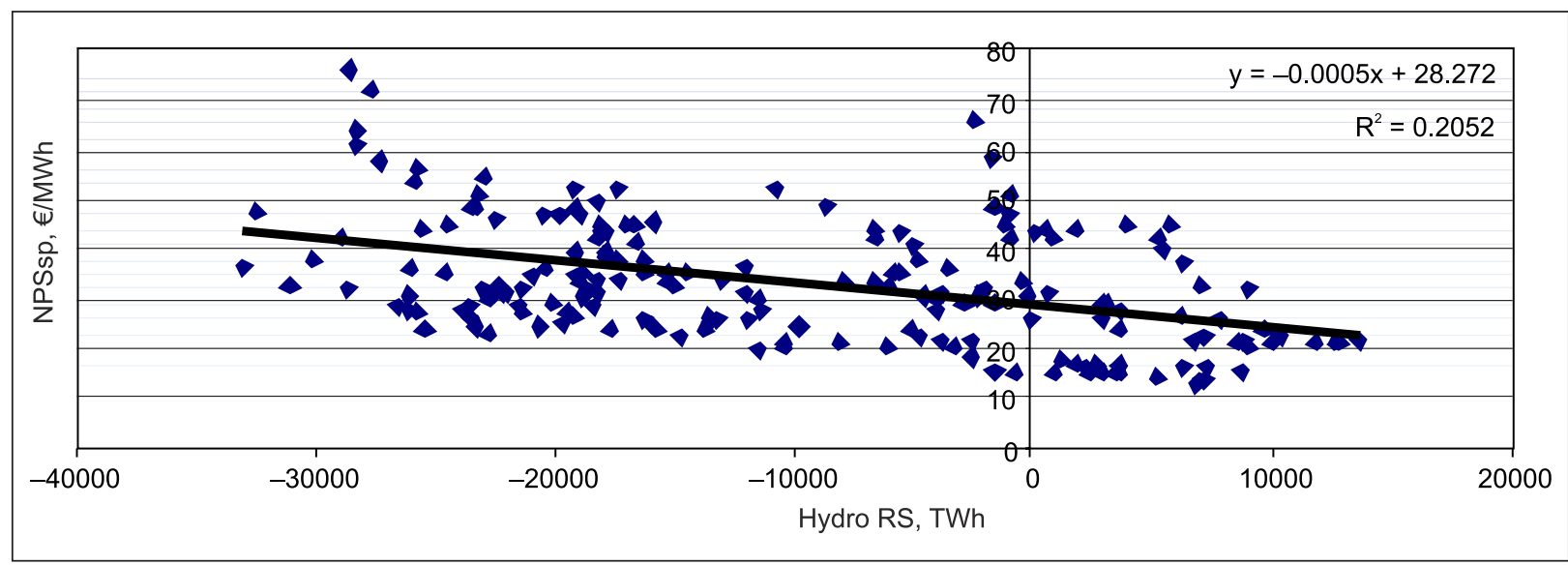

Fig. 7. Linear regression analysis of the second periods (2/3) of the years 2001-2011

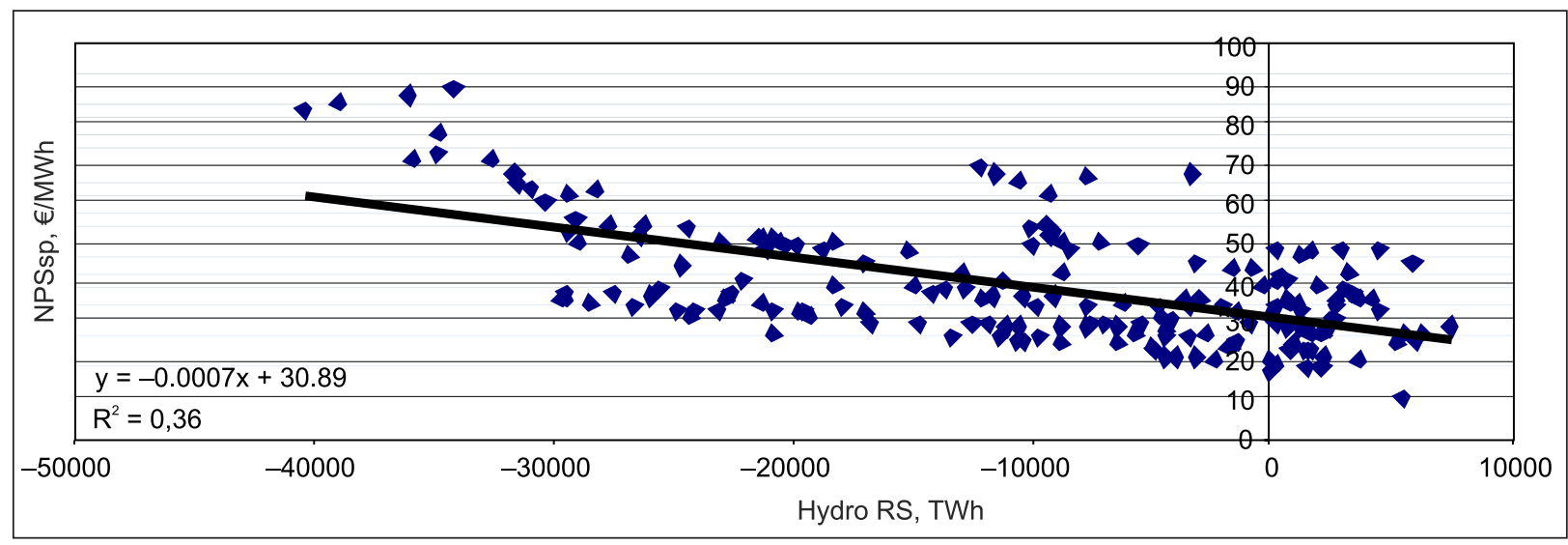

Fig. 8. Linear regression analysis of the third periods (3/3) of the years 2001-2011

customers to purchase electricity on the spot market. Two main groups of customers were recognized: "willing to pay" about 2,000 €/MWh that actually represents the maximum available bidding value on the Nord Pool Spot and the second group contains customers with bids in the range -200 to $2,000 € / \mathrm{MWh}$.

Short-term demand flexibility analysis reveals several important facts. Roughly $85 \%$ of consumers' buy bids are placed at the maximal available value of 2,000 € per MWh, thus only $15 \%$ could be assumed as at least partly flexible price responsive demand of which buy bids are placed within the range $-200 € / \mathrm{MWh}$ to $2,000 € / \mathrm{MWh}$. There are no significant distinguishable differences in the buy bidding behaviour between randomly selected days within the year as well as between the examined years as demonstrate the results of the analysis in the Figures below. 
a)

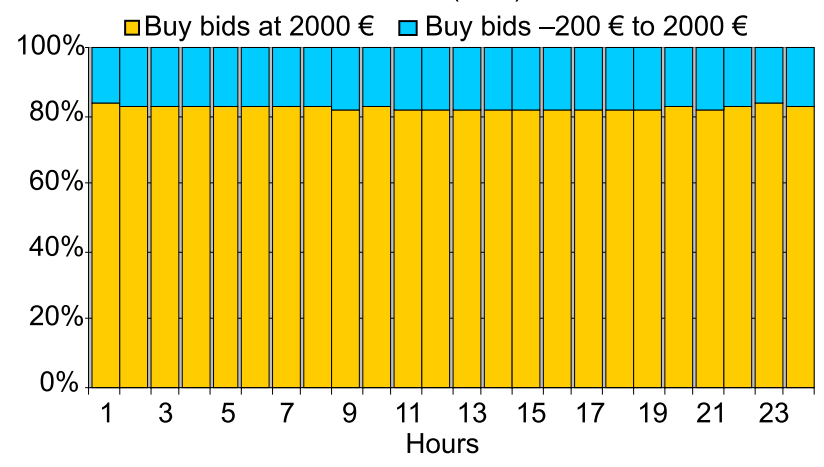

b)

9/09/2010 (24 h)

$\square$ Buy bids at $2000 € \square$ Buy bids $-200 €$ to $2000 €$

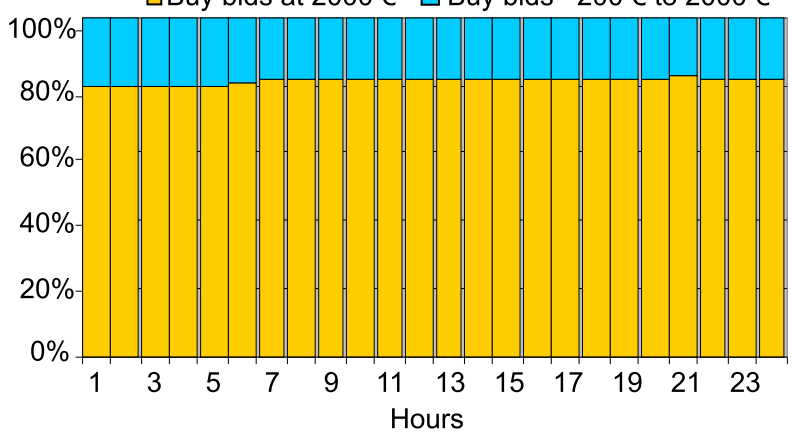

Fig. 9. One day buy-bidding analysis of NPS PX: a) 4 July 2010, b) 9 September 2010

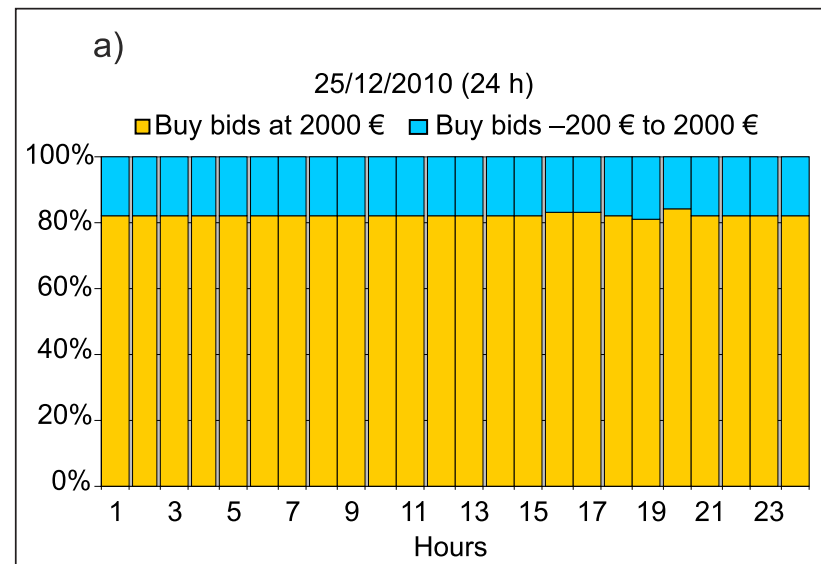

b)

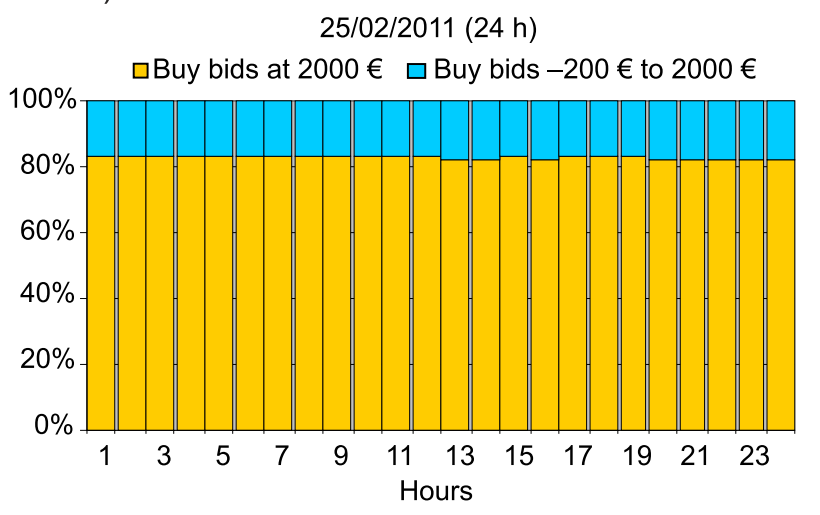

Fig. 10. One day buy-bidding analysis of NPS PX: a) 25 December 2010, b) 25 February 2011

a)

25/08/2011 (24 h)

$\square$ Buy bids at $2000 € \square$ Buy bids $-200 €$ to $2000 €$

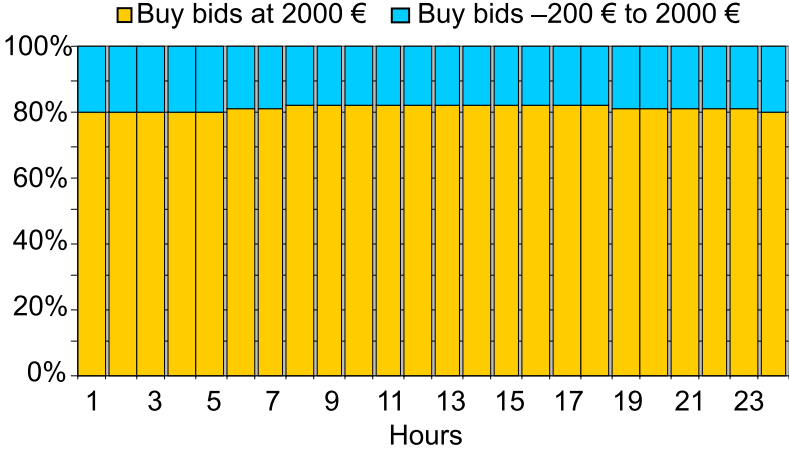

b)

25/02/2012 (24 h)

$\square$ Buy bids at $2000 € \square$ Buy bids $-200 €$ to $2000 €$

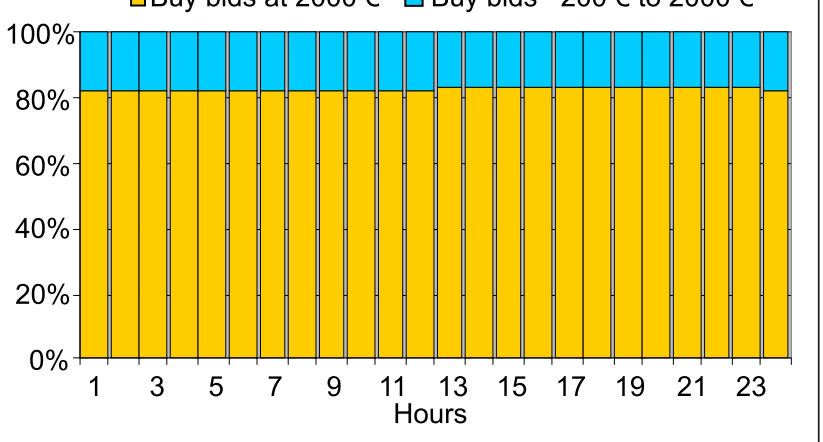

Fig. 11. One day buy-bidding analysis of NPS PX: a) 25 September 2011, b) 25 February 2012

Redrawing of the demand observations which are depicted in Figures 9, 10, 11 to the simplified demand slope with the price limits is made in Fig. 12.

The demand curve constructed from aggregated buy bids according to the results of the analysis may be characterized as a very low price responsive demand curve. Such price formation is nearly to markets with the pool price determination principle where only the supply side has active participation on price formation. This finding also has a weighty impact on the understanding of the price volatility since it could be an answer of unpredictable price spikes as well as a high intermittent volatility of the electricity price on the spot market. 


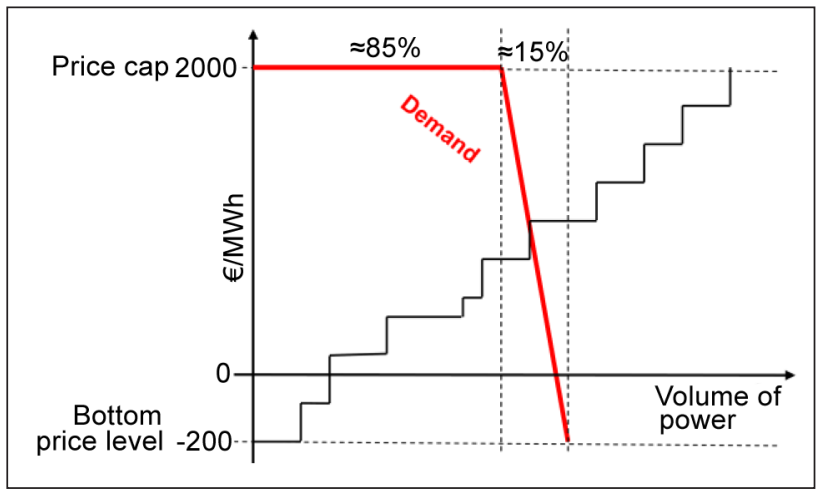

Fig. 12. Basic shape of estimated demand curve

\section{CONCLUSIONS}

The results of the analysis of the system price formation factors on the Nord Pool give the following assumptions about this market: a relatively high level of the positive correlation between the system price and assumed factors with considerable seasonal and annual differences. From the observation of seasonal linear trends of the system price and those factors it can be concluded that Gas and then Coal have the highest number of identical tendency with NPSsp from all investigated factors. This could be taken as confirmation of the fact that as marginal (price determining) generators on this market are often gas and coal-fired power plants. According to $\mathrm{CO}_{2}$ emissions, interesting is their relatively high correlation with NPSsp, even when generators received those allowances for free. This may be explained by the fact that now those allowances are assumed by generators as a usual commodity and therefore with the trading potential. Furthermore, those allowances are required by fossil-fuelfired power plants and those are, as was mentioned above, often marginal generators. The analysis also shows a high correlation between the hydro situation and NPSsp with high and typical seasonal variations.

From the analysis of the demand side, suprising is extremely low price responsiveness of consumers, the production side facing almost to the inflexible demand. This bidding strategy may be explained by reliance of consumers in this electricity market, however, such bidding strategy can contribute to occurrence of unpredictable and considerable price spikes during disturbances on the supply side.

The target of this article is related to assessment of impacts of fuels and emission allowances on the electricity price. However, it should be noted that correlation between fossil fuel prices as well as vice versa impacts, such as impacts of electricity prices on the fossil fuel prices and prices for emission allowances, could be possibly observed, assuming the fact that demand for property increases property prices.
Besides the analyzed factors, in liberalised imperfectly competitive environment, the possible price changing factor is represented by the abused market power of one or more involved competitors. This should be taken into account in further investigations as well. Furthermore, it might be expected that an increase of power production from intermitted generation sources with low marginal costs of production such as wind or photovoltaics will contribute to the increase of the price volatility on the spot markets as they provide an appropriate trading option for those hard foreseeable types of power production.

\section{ACKNOWLEDGEMENTS}

The paper is supported by the European Social Fund Project "Scientific Group Supporting Latvian Activities of the European Strategic Energy Technology Plan", No. 1DP/1.1.1.2.0/09/A-PIA/VIAA/027 and by Project VEGA SR No. 1/0414/12.

Received 22 June 2012 Accepted 10 August 2012

\section{References}

1. Chemisinec I., Marvan M., Necesany J., Sykora T., Tuma J. Obchod s elektřinou, (Market with Electricity), 1st Edition, CONTE spol s r. o., 2010. 201 p. (in Czech).

2. Junghans G., Oleinikova I., Obushevs A., Turcik M. How is electricity market price formed? (Kâ veidojas elektroeneriijas tirgus cena?). Energija un Pasaule. 2012. Vol. 72. No. 1. P. 42-45 (in Latvian).

3. Nord Pool Spot - Power Market Information. http://www. nordpoolsp-ot.com/Download-Centre/

4. Froeb Luke M., Mccann Brian T. Managerial Economics: A Problem-Solving Approach, 2nd Edition. Mason, $\mathrm{OH}$, USA: South-Western Cengage Learning, 2010. 352 p.

5. Rose K. The Impact of Fuel Costs on Electric Power Prices. June 2007. P. 25. http://appanet.cmsplus.com/files/ PDFs/ImpactofFuelCostsonElectricPowerPrices.pdf

6. Waron R. Modelling and Forecasting Electricity Loads and Prices: A Statistical Approach. Chichester, UK: John Wiley \& Sons, 2006. 192 p.

7. IEA, NEA, OECD. Projected Costs of Generating Electricity: 2010 Edition. Paris: OECD Publications, 2010. $218 \mathrm{p}$.

8. Harris C. Electricity Markets: Pricing, Structures and Economics. John Wiley \& Sons, 2006. 542 p.

9. Knoop G. Analysis of Economic Data. John Wiley \& Sons, Dec 2004. 256 p. 
Mario Turcik, Irina Oleinikova, Michal Kolcun

\section{ELEKTROS RINKOS KAINAS VEIKIANČIŲ FAKTORIŲ} STATISTINE் ANALIZE்

\section{Santrauka}

Darbo tikslas - išanalizuoti sistemos elektros biržos kainų formavimosi veiksnius, kuriuos lemia organizuota elektros rinka, apsikeitimo būdu valdoma Šiaurès šalių elektros „Nord Pool Spot“ biržos.

Istorinių duomenų analizè ir statistinis vertinimas atliktas siekiant nustatyti ir išanalizuoti veiksnius pagal kainos poveiki (atsižvelgiant ị sezoniškumą). Analizès rezultatai turètų pagerinti pagrindinių sistemos kainos formavimo veiksnių sampratą, atskleisti galimas sezoniškumo sistemos kainų svyravimų priežastis bei atskirus neprognozuojamus kainų šuolius, kuriais pasižymi elektros biržų rinka.

Raktažodžiai: elektros kaina, rinkos analizè, liberalizacija, elektros rinka
Марио Турцик, Ирина Олейникова, Михал Колцун

СТАТИСТИЧЕСКИЙ АНАЛИЗ ФАКТОРОВ

ВЛИЯЮЩИХ НА РЫНОЧНЫЕ ЦЕНЫ ЭЛЕКТРИЧЕСТВА

Резюме

Цель работы - проанализировать факторы формирования биржевых цен электричества, которые определяют организованный электро-рынок управляемый Северными странами „Nord Pool Spot“ биржами методом обмена электричеством.

Анализ исторических данных и статистическая оценка была выполнена с целью определения факторов по влиянию уровня сезонности. Результаты данного анализа должны улучшить понятия главных факторов формирования системных цен, раскрыть принципы колебания сезонных цен, а также единичные не прогнозируемые скачки цен существующие на биржевых рынках электричества.

Ключевые слова: цена электричества, анализ рынка, либерализация, рынок электричества 